\title{
Two related thrombin-like enzymes present in Bothrops atrox venom
}

J.H. Petretski1,

M. Kanashiro ${ }^{1}$,

C.P. Silva2,

E.W. Alves ${ }^{2}$ and

T.L. Kipnis ${ }^{1}$

\author{
Laboratórios de ${ }^{1}$ Biologia do Reconhecer and \\ ${ }^{2} \mathrm{Q}$ uímica e Função de Proteínas e Peptídeos, \\ Universidade Estadual do N orte Fluminense, \\ Campos dos Goytacazes, RJ, Brasil
}

\section{Correspondence \\ T.L. Kipnis \\ Laboratório de Biologia \\ do Reconhecer \\ Centro de Biociências e \\ Biotecnologia, UENF \\ Av. Alberto Lamego, 2000 \\ 28015-620 Campos dos Goytacazes, RJ \\ Brasil \\ E-mail: kipnis@cbb.uenf.br \\ J.H. Petretski is the recipient of a FEN O RTE scholarship. T.L. Kipnis and E.W. Alves are recipients of CNPq, FENORTE, and FINEP grants.}

Received June 30, 1999 Accepted August 18, 2000

\section{Abstract}

This article describes the presence of two new forms of a thrombinlike enzyme, both with apparent molecular masses of $38 \mathrm{kDa}$, in Bothrops atrox venom. Both share the ability to cleave fibrinogen into fibrin and to digest casein. Both present identical $K_{\mathrm{m}}$ on the substrate $\mathrm{BA} p \mathrm{NA}$. Their N-terminal amino acid sequences are identical for 26 residues, sharing $80 \%$ homology with batroxobin and flavoxobin. Two groups of monoclonal antibodies (mAbs) raised against the purified enzyme forms recognized different epitopes of the putative corresponding enzymes present in B. atrox crude venom. On Western blotting analysis of $B$. atrox crude venom, mAbs 5DB2C8, 5AA10 and 5CF11, but not mAbs 6CC5 and 6AD2-G5, revealed two or more protein bands ranging from 25 to $38 \mathrm{kDa}$. By immunoprecipitation assays, the 6AD2-G5 mAb was able to precipitate protein bands of 36$38 \mathrm{kDa}$ from B. atrox, B. leucurus, B. pradoi, B. moojeni, B. jararaca and $B$. neuwiedii crude venoms. Fibrinogen-clotting activity was inhibited when the same venom specimens were pre-incubated with mAb 6AD2-G5, except for B. jararaca and B. neuwiedii.
Key words

- Venoms

- Bothrops atrox

- Enzymes

- Thrombin-like enzymes

- Blood coagulation system

\section{Introduction}

The snake venom serine proteinase family includes enzymes that transform mammalian fibrinogen into fibrin fibers (1-3), activate clotting factor $\mathrm{V}(4,5)$ and plasma protein $\mathrm{C}(6,7)$, release kinins from kallikreinogen $(8,9)$ and cleave the complement $\mathrm{C} 3$ component (10).

We have recently shown that the thrombin-like Bothrops atrox venom component from two different Amazon regions, i.e., Manaus and Tucuruí, presented distinct chro- matographic profiles and capacity to clot fibrinogen. The thrombin-like activity was isolated as a $32-\mathrm{kDa}$ protein which was recognized and neutralized by horse hyperimmune serum anti-Bothrops whole venom (11).

In this article, we present data indicating that highly purified $B$. atrox thrombin-like preparations contain at least two forms of the enzyme. Both clot purified bovine fibrinogen and hydrolyze a synthetic substrate, although exhibiting small differences in their molecular masses and in binding affinity for ion-exchange resins. Moreover, the enzymes 
share $80 \% \mathrm{~N}$-terminal sequence homology with the thrombin-like enzyme described for B. moojeni (12). We also describe monoclonal antibodies able to recognize and efficiently neutralize the thrombin-like enzymes of the B. atrox snake group but not able to discriminate between the two forms of thrombin-like activity.

\section{Material and Methods}

\section{Venoms, resins and reagents}

Bothrops atrox venom was provided by the Laboratório de Herpetologia, Instituto Butantan, São Paulo, SP, Brazil. This snake colony was originally started with specimens captured in Tucuruí, Pará, Brazil. Venom was filtered through a $0.45-\mu \mathrm{m}$ membrane, lyophilized, divided into $10-\mathrm{mg}$ aliquots and stored at $-20^{\circ} \mathrm{C}$.

Sephacryl S-100-HR and cyanogen bromide-activated Sepharose-4B were purchased from Pharmacia Fine Chemicals (Uppsala, Sweden) and the HPLC column DEAE-5PW was purchased from BioRad Laboratories (Hercules, CA, USA). Bovine fibrinogen type IV, EDTA, and the synthetic substrates N(-benzoyl-L-arginine- $p$-nitroanilide (BA $p$ NA), N-succinyl-Ala-Ala-ProLeu- $p$-nitroanilide, N-succinyl-Ala-Ala-ProPhe- $p$-nitroanilide and other reagents were purchased from Sigma Chemical Co. (St. Louis, MO, USA). The molecular weight markers illustrated in Figure 3 were $66 \mathrm{kDa}$ (bovine serum albumin), $45 \mathrm{kDa}$ (egg albumin), $29 \mathrm{kDa}$ (carbonic anhydrase), $18 \mathrm{kDa}$ (ß-lactoglobulin), and $14 \mathrm{kDa}$ (lysozyme) from Sigma. The Mid-Range Protein Molecular Weight Markers from Promega Corporation (Madison, WI, USA) are listed in Figures 4 and 5.

\section{Purification of fibrinogen-clotting activity from $B$. atrox venom}

Venom samples of $50 \mathrm{mg}$ dry weight were dissolved in $2.5 \mathrm{mM}$ Tris- $\mathrm{HCl}$ buffer, $\mathrm{pH} 7.5$, plus $150 \mathrm{mM} \mathrm{NaCl}$ and centrifuged to remove insoluble particles. The supernatant was applied to a Sephacryl S-100-HR $(2.5 \times 67 \mathrm{~cm})$ column equilibrated with the same buffer. The flow rate was $1.3 \mathrm{ml} / \mathrm{min}$ and fractions of $2.5 \mathrm{ml}$ were collected. Each fraction was assayed for fibrinogen-clotting activity and protein concentration was monitored at $280 \mathrm{~nm}$. The fractions containing fibrinogen-clotting activity were pooled, concentrated by lyophilization and dialyzed against $2.5 \mathrm{mM}$ Tris-HCl buffer, $\mathrm{pH} 7.5$. The pooled activity was applied to an HPLC anion-exchange column (DEAE-5PW, BioRad) equilibrated with $2.5 \mathrm{mM}$ Tris- $\mathrm{HCl}$ buffer, $\mathrm{pH}$ 7.5. Elution was performed with an $\mathrm{NaCl}$ gradient. The resulting fractions were assayed for fibrinogen-clotting activity and protein concentration was monitored at $280 \mathrm{~nm}$. Two pools containing fibrinogenclotting activity were obtained. The pools were named TLE1 and TLE2 (thrombin-like enzyme), concentrated by lyophilization, dialyzed against $2.5 \mathrm{mM}$ Tris- $\mathrm{HCl}$ buffer, $\mathrm{pH}$ 7.5, and stored at $-20^{\circ} \mathrm{C}$.

\section{Fibrinogen-clotting assay}

Clotting time was determined by mixing $50 \mu 1$ of the sample to be tested with $400 \mu 1$ of purified bovine fibrinogen $(2 \mathrm{mg} / \mathrm{ml}), 25$ $\mathrm{mM}$ Tris- $\mathrm{HCl}$ buffer, $\mathrm{pH} 8.0$, plus $150 \mathrm{mM}$ $\mathrm{NaCl}$ at $25^{\circ} \mathrm{C}$. A unit of fibrinogen-clotting enzyme was arbitrarily defined as the amount of enzyme preparation capable of coagulating the fibrinogen solution in $1 \mathrm{~min}$.

\section{Enzyme assays and determination of kinetic parameters}

Thrombin-like enzyme activity on $p$-nitroanilide substrates was assayed in $50 \mathrm{mM}$ Tris- $\mathrm{HCl}, \mathrm{pH} 8.0$, at room temperature. The reaction was performed in a volume of 0.5 $\mathrm{ml}$ and was started by adding the enzyme at a final concentration of $4.0 \mu \mathrm{g} / \mathrm{ml}$. Substrate 
hydrolysis was monitored by measuring the increase in absorbance at $410 \mathrm{~nm}$. For the determination of Michaelis constant $\left(K_{\mathrm{m}}\right)$ and catalytic constants $\left(k_{\mathrm{cat}}\right)$, at least 7 substrate concentrations were used. $K_{\mathrm{m}}$ and $k_{\text {cat }}$ were calculated according to Aguiar et al. (13). The following $p$-nitroanilide substrates were used: BApNA, N-succinyl-Ala-AlaPro-Leu- $p$-nitroanilide and N-succinyl-AlaAla-Pro-Phe- $p$-nitroanilide. To determine the effect of monoclonal antibodies on the enzyme activity, appropriate dilutions of each antibody were incubated with the enzyme preparations for $30 \mathrm{~min}$ in $50 \mathrm{mM}$ Tris- $\mathrm{HCl}$, $\mathrm{pH} 8.0$, followed by the addition of $120 \mathrm{mM}$ of substrate. BA $p$ NA hydrolysis was recorded by the absorbance change at $410 \mathrm{~nm}$. Inhibition activity was calculated on the basis of at least 5 experiments and is reported as percent.

\section{$\mathrm{N}$-terminal sequence determination}

$\mathrm{N}$-terminal sequences of the purified proteins were analyzed on a Shimadzu PPSQ-10 Automated Protein Sequencer by Edman degradation. PTH-amino acids were detected at $269 \mathrm{~nm}$ after separation on a reverse phase C18 column $(4.6 \times 250 \mathrm{~mm})$ under isocratic conditions according to manufacturer instructions. Sequence homology and alignments were determined using the BLAST NCBI algorithm (14).

\section{Monoclonal antibody (mAb) production}

$\mathrm{BALB} / \mathrm{c}$ mice were immunized with TLE2 both before (mAbs: 6AD2-G5, 6CC5) and after SDS-PAGE separation (mAbs: 5BA9, 5DB2C8, 5AA10, 5CF11, 5DC2) using $\mathrm{Al}(\mathrm{OH})_{3}$ as adjuvant. Sixteen days later a booster injection was applied with the corresponding antigens without adjuvant. Spleen cells were harvested on day 30 and fused with NSO myeloma cells according to Köhler and Milstein (15). The supernatants of hybrid cells were screened by ELISA or
Western blot methods. These supernatants were also screened for the ability of mAbs to block the fibrinogen-clotting activity present in total $B$. atrox venom or in purified thrombin-like preparations.

\section{Immunoprecipitation}

Twenty $\mathrm{mg}$ of $\mathrm{CNBr}$-activated Sepharose-4B was equilibrated with $0.5 \mathrm{M} \mathrm{HCl}$

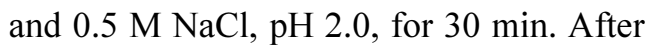
washing the gel with $100 \mathrm{mM}$ carbonate buffer, $\mathrm{pH}$ 9.0, containing $0.5 \mathrm{M} \mathrm{NaCl}, 20$ $\mathrm{mg}$ of $\mathrm{mAb}$ was added. The mixture was then incubated under gentle shaking for $4 \mathrm{~h}$ at room temperature, followed by $16 \mathrm{~h}$ at $4^{\circ} \mathrm{C}$. The gel was washed with $10 \mathrm{mM}$ Tris- $\mathrm{HCl}$ buffer, pH 8.0, containing $0.1 \mathrm{M} \mathrm{NaCl}, 0.1 \%$ sodium azide and $0.1 \%$ Nonidet $\mathrm{P} 40$, followed by the addition of the antigen. The mixture was incubated at $37^{\circ} \mathrm{C}$ for $1 \mathrm{~h}$. The gel was washed with the same buffer, centrifuged and resuspended in $50 \mu 1$ of SDSPAGE sample buffer, boiled at $100^{\circ} \mathrm{C}$ for 10 min, and applied to a $12 \%$ polyacrylamide gel. Protein bands were detected by Coomassie blue.

\section{Results}

B. atrox venom was fractionated on Sephacryl S-100-HR and the fibrinogen-clotting activity was assayed. The fibrinogenclotting activity reached its maximum at the elution volume of $190 \mathrm{ml}$ (Figure 1A), in a region where the caseinolytic hydrolysis was low (Figure 1B), suggesting that the observed fibrinogen-clotting activity is a specific proteolytic activity not able to hydrolyze casein.

Fractions containing more than 10 units/ $\mathrm{ml}$ of fibrinogen-clotting activity were pooled (Sephacryl pool), concentrated and applied to a DEAE-5PW HPLC anion-exchange column eluted with an $\mathrm{NaCl}$ gradient. Two protein peaks presenting fibrinogen-clotting activity were eluted and denoted TLE1 and TLE2, as 

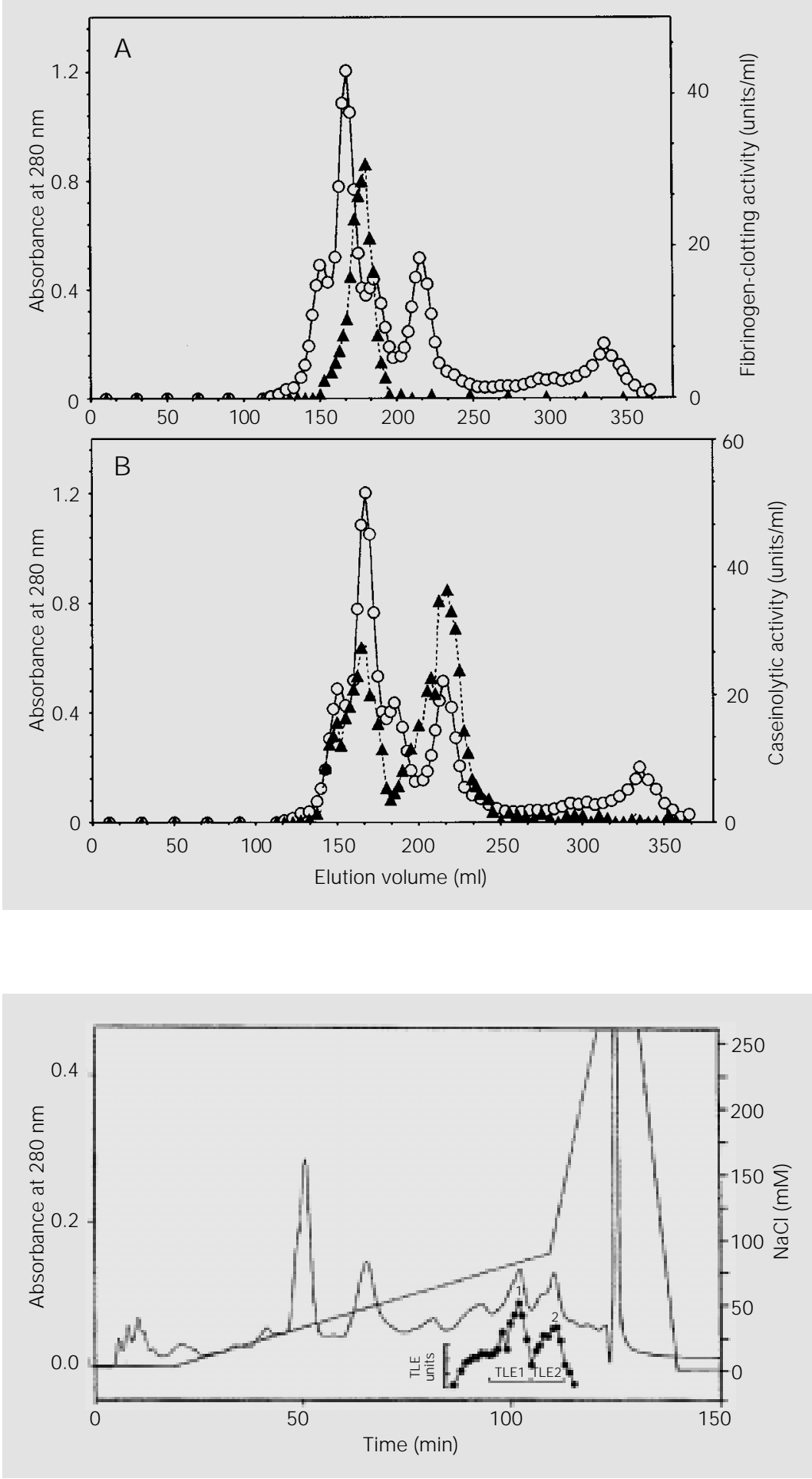

Figure 2 - Ion-exchange chromatography. The gel-filtered thrombin-like activity (Figure 1A) was applied to a DEAE-5PW (BioRad) HPLC column, equilibrated with $2.5 \mathrm{mM}$ Tris-HCl, $\mathrm{pH}$ 7.5 , and eluted with an $\mathrm{NaCl}$ gradient. Absorbance was monitored at $280 \mathrm{~nm}$. Thrombin-like activity (filled circles) was estimated as described in Material and Methods. Peaks 1 and 2 were pooled as indicated by bars and are denoted TLE1 and TLE2.
Figure 1 - Size exclusion chromatography of crude B. atrox venom ( $50 \mathrm{mg}$ ) on a Sephacryl S-100-HR column $(2.5 \times 67.0 \mathrm{~cm})$. The venom was solubilized in $25 \mathrm{mM}$ Tris- $\mathrm{HCl}, \mathrm{pH}$ 7.5, plus $150 \mathrm{mM} \mathrm{NaCl}$. Protein concentration was monitored at $280 \mathrm{~nm}$ (circles). A, Thrombinlike activity is indicated by triangles. B, Caseinolytic activity is indicated by triangles.

indicated in Figure 2. Table 1 shows a summary of the purification steps, resulting in an enrichment of 37 -fold with $7 \%$ recovery of activity in relation to crude venom.

The electrophoretic profile of $B$. atrox crude venom and TLE1 and TLE2 after purification is shown in Figure 3. The TLE1 and TLE2 proteins resulting from the ion-exchange step appear as bands of $38 \mathrm{kDa}$. Computed densitometric analysis (16) was used to estimate the extent of homogeneity as $95 \%$ for both proteins, indicating the existence of minor contaminants with a molecular mass of about 30 to $32 \mathrm{kDa}$.

Table 2 shows that both enzymes presented a similar kinetic behavior. TLE1 and TLE2 $K_{\mathrm{m}}$ for BApNA were not significantly different, and both enzymes failed to hydrolyze efficiently the other substrates used. Among the synthetic substrates used to assay the enzymatic activities of TLE1 and TLE2, BApNA was the one most rapidly hydrolyzed (Table 2) and was used in the inhibition experiments. The enzymatic activity of TLE1 was significantly blocked by $1 \mathrm{mM}$ PMSF (28\% inhibition) and by $10 \mu \mathrm{g}$ of the mAb 6AD2-G5 (53\% inhibition). The enzyme was insensitive to $0.001 \mathrm{mM}$ pepstatin, $10 \mathrm{mM}$ EDTA and $0.01 \mathrm{mM}$ E-64 (data not shown). When tested with the same inhibitors, TLE2 presented identical behavior, supporting the conclusion that TLE1 and TLE2 are serine proteinases.

The first $26 \mathrm{~N}$-terminal amino acid residues of both TLE1 and TLE2 are identical (Table 3). When compared with published sequences for related proteins, homology was observed to be around $80 \%$ with batroxobin (12) and flavoxobin (17). 
The protein profile of $B$. atrox crude venom was visualized with the mAbs against purified TLE2 by Western blotting (Figure 4). The mAbs 5BA9 (lane 1) and 5DB2C8 (lane 2) revealed strong protein bands with molecular masses of around 32 to $38 \mathrm{kDa}$. The apparent thickness of the bands suggests more than one protein component. The $\mathrm{mAb}$ 5AA10 (lane 3) revealed two faint protein bands, with molecular masses of about 35 and $25 \mathrm{kDa}$, respectively; mAb 5CF11 (lane 4) obtained two distinct but close protein bands with molecular masses of $38 \mathrm{kDa}$; $\mathrm{mAb} 5 \mathrm{DC} 2$ (lane 5) reacted with four distinct protein bands with molecular masses ranging from 26 to $38 \mathrm{kDa} ; \mathrm{mAbs} 6 \mathrm{CC} 5$ (lane 6) and 6AD2-G5 (lane 7) were unable to react with protein bands within the 25 to $39 \mathrm{kDa}$ range of molecular mass, although a faint band with a molecular mass lower than $14 \mathrm{kDa}$ was observed in lane 6 . The unrelated anti-human heat shock protein HSP70 $\mathrm{mAb}$ (lane 8) did not react with any B. atrox venom protein band.

The apparent inability of mAb 6AD2-G5 (Figure 4, lane 7) to react with electrotransferred crude venom proteins could be attributed to the denaturating conditions used in Western blotting. We hypothesize that $\mathrm{mAb}$ 6AD2-G5 may be directed at a conformational rather than a structural epitope. If this were the case, its conformation could be disarranged during the Western blotting procedure. To test this hypothesis, mAb 6AD2G5 was immobilized on CNBr Sepharose$4 \mathrm{~B}$ and used to immunoprecipitate the specific antigens present in whole $B$. atrox venom. Under these conditions, the epitope recognized by mAb 6AD2-G5 was preserved and 36-38-kDa protein bands were detected in B. leucurus, B. pradoi, B. jararaca, $B$. neuwiedii, $B$. moojeni, and $B$. atrox venom (Figure 5). The fibrinogen-clotting activity present in these venoms, but not in $B$. jararaca or $B$. neuwiedii venoms, was extensively blocked when samples were pre-incubated with mAb 6AD2-G5 (Table 4).
Table 1 - Purification of thrombin-like enzyme (TLE) from B. atrox venom.

Activity was measured with bovine fibrinogen.

\begin{tabular}{lcccccc}
\hline Step & $\begin{array}{c}\text { Protein } \\
(\mathrm{mg})\end{array}$ & $\begin{array}{c}\text { Protein } \\
(\%)\end{array}$ & $\begin{array}{c}\text { Total } \\
\text { activity (U) }\end{array}$ & $\begin{array}{c}\text { Specific } \\
\text { activity (U/mg) }\end{array}$ & $\begin{array}{c}\text { Yield } \\
(\%)\end{array}$ & $\begin{array}{c}\text { Purification } \\
\text { factor }\end{array}$ \\
\hline Crude venom & 50 & 100 & 4200 & 84 & 100 & 1 \\
Sephacryl pool & 2.1 & 4.2 & 1113 & 530 & 27 & 6 \\
TLE1 + TLE2 & 0.1 & 0.2 & 310 & 3100 & 7 & 37
\end{tabular}

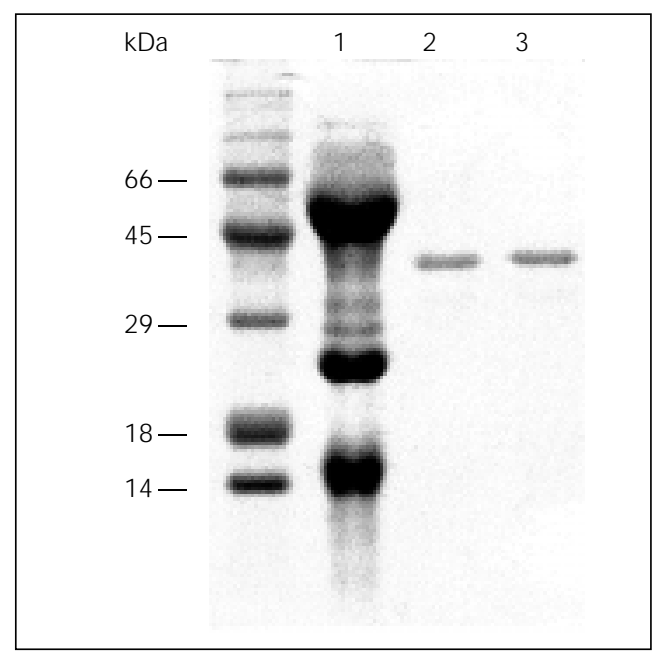

Figure 3 - SDS-polyacrylamide gel electrophoresis of purified thrombin-like enzymes (TLE) from Bothrops atrox venom. Samples were submitted to electrophoresis on $12 \%$ slab ge containing $1 \%$ SDS. Proteins were denaturated by heating. Lane 1, $60 \mu \mathrm{g}$ of crude venom Lane 2, $1 \mu \mathrm{g}$ of TLE1. Lane 3, 1 $\mu \mathrm{g}$ of TLE2.

Table 2 - Kinetic parameters for the thrombin-like enzyme (TLE)-catalyzed hydrolysis of peptide chromogenic substrates.

aFor TLE1; bfor TLE2. NDA, Non-detectable activity under the experimental conditions for both preparations (TLE1 and TLE2). ND, Not determined (superior to $25 \mathrm{mM}$ ) for both preparations.

\begin{tabular}{lccc}
\hline Substrate & $\mathrm{K}_{\mathrm{m}}\left(10^{-4} \mathrm{M}\right)$ & $\mathrm{k}_{\text {cat }}\left(10^{3} \mathrm{~s}^{-1}\right)$ & $\mathrm{k}_{\text {cat }} / \mathrm{K}_{\mathrm{m}}\left(10^{6} \mathrm{M}^{-1} \mathrm{~s}^{-1}\right)$ \\
\hline BApNA $^{\mathrm{a}}$ & $3.3 \pm 0.4$ & 3.2 & 9.6 \\
BApNA $^{\mathrm{b}}$ & $4.6 \pm 0.5$ & 1.9 & 4.1 \\
N-S-Ala-Ala-Pro-Leu-pNA & NDA & - & - \\
N-S-Ala-Ala-Pro-Phe-pNA & ND & - & -
\end{tabular}

Table 3 - N-terminal sequence of the two forms of B. atrox thrombin-like enzyme (TLE) and comparison with other proteases.

1Present study; ${ }^{2}$ Ref. 12; ${ }^{3}$ Ref. 17.

\begin{tabular}{|c|c|}
\hline Enzyme & $\mathrm{N}$-terminal sequence \\
\hline B. atrox TLE $1^{1}$ & $\mathrm{VIMX} D \mathrm{EX}$ D I N E S P F L A F M Y Y \\
\hline B. atrox TLE2 ${ }^{1}$ & $\mathrm{VIMXDEXDINESPFLAFMYY} \mathrm{PQYF}$ \\
\hline Batroxobin ${ }^{2}$ & VI G G D E C D I N E P F L AF MYYSPR F \\
\hline Flavoxobin ${ }^{3}$ & V I G G D E C D I N E H P F L V A L Y D A W S G R F \\
\hline
\end{tabular}




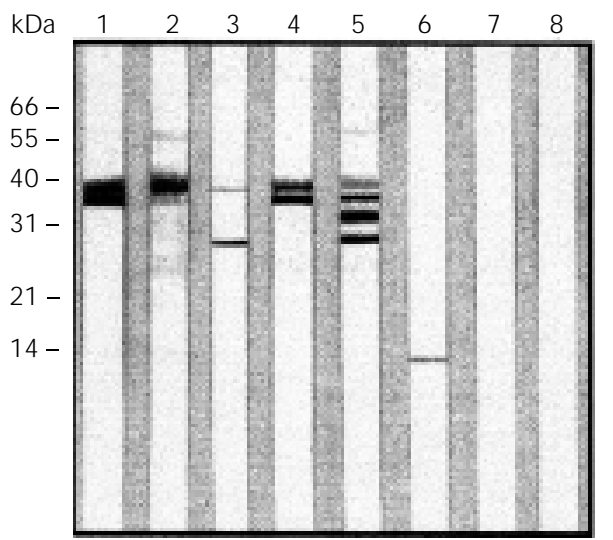

Figure 4 - Western blotting analysis using mAbs against B. atrox thrombin-like enzymes. Crude venom was submitted to SDS-PAGE (12\% acrylamide), electrotransferred to a nitrocellulose membrane and each strip was reacted with $\mathrm{mAbs}$ as described in Material and Methods. Lane 1, 5BA9; lane 2, 5DB2C8; lane 3, 5AA10; lane 4, 5CF11; lane 5, 5DC2; lane 6, 6CC5; lane 7, 6AD2-G5; lane 8, anti-human HSP70 mAb.

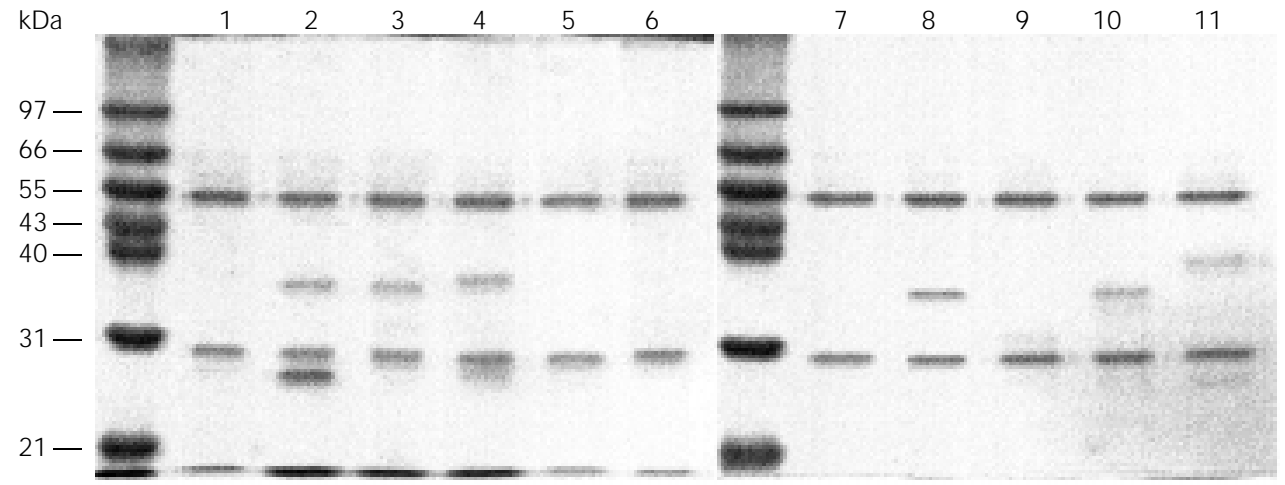

Figure 5 - SDS-PAGE (12\% acrylamide) of immunoprecipitated venom proteins of Bothrops species by 6AD2-G5 immobilized on Sepharose-4B. Bands close to the 55,000 and 31,000 markers, present in all slots, are the heavy and light IgG fractions. The amounts of venom used in the immunoprecipitation experiments are given in parentheses. Lane 1, B. fonsecai $(0.41 \mathrm{mg})$; lane 2, B. leucurus $(0.58 \mathrm{mg})$; lane 3, B. pradoi $(0.41 \mathrm{mg})$; lane 4, B. jararaca $(0.54 \mathrm{mg})$; lane 5 , B. insularis $(0.28 \mathrm{mg})$; lane 6 , B. cotiara $(0.25 \mathrm{mg})$; lane 7 , B. alternatus $(0.33 \mathrm{mg})$; lane 8 , B. neuwiedii $(0.33 \mathrm{mg})$; lane 9, B. jararacussu $(0.33 \mathrm{mg})$; lane 10 , B. moojeni $(0.30 \mathrm{mg})$; lane 11 , B. atrox $(0.64 \mathrm{mg})$

Table 4 - Inhibition of fibrinogen-clotting activity by mAb 6AD2-G5.

The amount of venom or purified thrombin-like enzyme (TLE1) preparation used in the assay is given in parentheses. The fibrinogen-clotting activity (FCA) was measured as described in Material and Methods. Before addition of bovine fibrinogen solution, the venom or purified TLE1 was incubated with mAb 6AD2-G5 for 10 min at $37^{\circ} \mathrm{C}$. The $I_{50}$ assay was performed with several concentrations of mAb $6 A D 2-G 5$ in order to estimate the $\mathrm{mAb}$ concentration necessary to inhibit $50 \%$ of the fibrinogen-clotting activity.

\begin{tabular}{|c|c|c|c|c|}
\hline Venom & $\begin{array}{l}\text { FCA units without } \\
\text { 6AD2-G5 }\end{array}$ & $\begin{array}{l}\text { FCA units with } \\
\text { 6AD2-G5 }(100 \mu \mathrm{g})\end{array}$ & $\begin{array}{c}\mathrm{FCA} \\
\text { remaining (\%) }\end{array}$ & $\mathrm{IC}_{50}(\mu \mathrm{g})$ \\
\hline B. atrox TLE1 $(0.22 \mu \mathrm{g})$ & 1.30 & 0.0 & 0 & 0.2 \\
\hline B. atrox (crude venom, $25.6 \mu \mathrm{g}$ ) & 0.70 & 0.14 & 20 & 1.3 \\
\hline B. moojeni (crude venom, $23.6 \mu \mathrm{g}$ ) & 0.75 & 0.11 & 16 & 0.3 \\
\hline B. leucurus (crude venom, $34.5 \mu \mathrm{g}$ ) & 0.71 & 0.07 & 10 & 1.6 \\
\hline B. pradoi (crude venom, $32.8 \mu \mathrm{g}$ ) & 0.63 & $<0.04$ & $<6$ & 1.0 \\
\hline B. neuwiedii (crude venom, $39.0 \mu \mathrm{g}$ ) & 0.26 & 0.21 & 81 & - \\
\hline B. jararaca (crude venom, $43.2 \mu \mathrm{g}$ ) & 0.75 & 0.50 & 67 & - \\
\hline B. cotiara (crude venom, $50.0 \mu \mathrm{g}$ ) & 0.15 & 0.15 & 100 & - \\
\hline B. alternatus (crude venom, $65.0 \mu \mathrm{g}$ ) & 0.21 & 0.21 & 100 & - \\
\hline B. insularis (crude venom, $11.2 \mu \mathrm{g}$ ) & 0.79 & 0.75 & 95 & - \\
\hline B. fonsecai (crude venom, $82.0 \mu \mathrm{g}$ ) & 0.22 & 0.20 & 91 & - \\
\hline B. jararacussu (crude venom, $33.0 \mu \mathrm{g}$ ) & 0.17 & 0.17 & 100 & - \\
\hline
\end{tabular}




\section{Discussion}

Edema and pain are the earliest local symptoms following injection of Bothrops venom into the victim's skin. Thereafter, leukocyte infiltration, hemorrhage and intravascular thrombus formation may sometimes lead to severe tissue destruction (18). Hypotension, blood incoagulability with intense fibrinogen consumption and respiratory distress are concurrent systemic symptoms. Depending on the amount of venom injected, kidney failure and death are possible outcomes (19).

The snake venom serum proteases through their fibrinogen-converting activities (2), blood clotting factor $\mathrm{V}$ and protein $\mathrm{C}$-activating enzymes (4-6), and C3-converting enzymes (10) are probably the most important mediator inducers of the tissue damage and symptoms provoked by Bothrops venoms.

The purification and characterization of two new forms of thrombin-like enzyme were reported here. Fibrinogen-clotting activities were concentrated into two closely related fractions, called TLE1 and TLE2, after serial chromatography on Sephacryl S-100-HR and DEAE-5PW. These fractions together, although representing only $7 \%$ of the total activity contained in the starting crude venom, have high specific activity $(3100 \mathrm{U} / \mathrm{mg})$ corresponding to 37 times purification (Table 1). Both enzymes are almost equally active on synthetic specific substrates such as $\mathrm{BA} p \mathrm{NA}$, suggesting that their active enzymatic sites are functionally similar. The capacity of TLE1 to hydrolyze the synthetic substrate was efficiently inhibited by $\mathrm{mAb}$ 6AD2-G5.

The purified proteins have similar molecular masses of $38 \mathrm{kDa}$ (Figure 3). When amounts above $10 \mu \mathrm{g}$ of TLE1 or TLE2 are submitted to SDS-PAGE (15\%), a second band with a molecular mass of approximately $32 \mathrm{kDa}$ becomes visible probably corresponding to the thrombin-like enzyme previously described by Cavinato et al. (11). These data, and the distinct elution profiles exhibited by the two enzymes (TLE1 and TLE2) on DEAE-5PW ion-exchange chromatography strongly suggest that although they contain similar enzymatic active sites they are distinct molecules. As the amino acid sequencing data presented in this paper did not extend beyond residue 26, differences in the primary structure could be present beyond this residue. Alternatively, the molecular differences between the two enzymes could be ascribed to the extent of glycosylation of their respective polypeptide chains. This possibility is likely since thrombin-like enzymes exhibiting microheterogeneity due to differences in their polypeptide chain glycosylation have been reported in venoms from Agkistrodon rhodostoma $(20,21)$ Crotalus horridus horridus (22), Lachesis muta muta (23), Bothrops jararaca (24) and Bothrops jararacussu (25).

The N-terminal sequences of the TLE1 and TLE2 proteins have a high homology, around $80 \%$, compared to published sequences for related proteins such as batroxobin and flavoxobin $(12,19)$.

Since most assayed mAbs were able to recognize and precipitate protein components present in $B$. atrox crude venom, it was interesting to determine if they could also block the thrombin-like component against which they were raised. In preliminary experiments, we found that such activity was exhibited only by mAbs 5DB2C 8 and 6AD2$\mathrm{G} 5$. The latter $\mathrm{mAb}$ significantly blocked the fibrinogen-clotting activity present in $B$. atrox (80\% inhibition), B. leucurus (90\% inhibition), B. moojeni (84\% inhibition), and $B$. pradoi (94\% inhibition), as well as the purified thrombin-like activity of $B$. atrox venom.

The ability of mAb 6AD2-G5 to efficiently neutralize the fibrinogen-clotting activity only of venoms from $B$ atrox, $B$. leucurus, $B$. pradoi and B. moojeni supports the view that these species are highly correlated and distinct from the other Bothrops species (26). On the other hand, the mAb 
was also able to recognize and inhibit with lower efficiency fibrinogen-clotting enzymes from $B$. jararaca and $B$. neuwiedii venoms. This mAb may be a valuable tool for the rapid purification of sufficient amounts of these proteins to be used in more refined experiments.

\section{Acknowledgments}

The authors thank Instituto Butantan for providing the venoms and Nichole Danraj for carefully reviewing the manuscript.

\section{References}

1. Stocker K \& MeierJ (1988). Thrombin-like snake venom enzymes. In: Pirkle $\mathrm{H} \&$ Markland FS (Editors), Hemostasis and Animal Venoms. Marcel Dekker, New York.

2. Pirkle H \& Theodor I (1991). Thrombin-like enzymes from snake venoms. In: Tu AT (Editor), Handbook of Natural Toxins. Vol. 5. Reptile Venoms and Toxins. Pergamon Press, London.

3. Zhang $Y$, Gao R, Lee WH, Zhu SW, Xiong YL \& Wang WY (1998). Characterization of a fibrinogen-clotting enzyme from Trimeresurus stejnegeri venom and comparative study with other venom proteases. Toxicon, 36: 131-142.

4. Kisiel W (1979). Molecular properties of the factor $V$-activating enzyme from Russell's viper venom. J ournal of Biological Chemistry, 254: 12230-12234.

5. Tokunaga F, Nagasawa K, Tamura S, Miyata T, Iwanaga S \& Kisiel W (1988). The factor V-activating enzyme (RVV-V) from Russell's viper venom. Identification of isoproteins RV-Va, - $\mathrm{Vb}$ and $-\mathrm{Vr}$ and their complete amino acid sequence. J ournal of Biological Chemistry, 263: 17471-17481.

6. Kisiel W, Kondo S, Smith KJ , McMullen BA \& Smith LF (1987). Characterization of a protein $C$ activator from Agkistrodon contortrix contortrix venom. J ournal of Biological Chemistry, 262: 12607-12613.

7. McMullen BA, Fujikawa $K \&$ Kisiel $W$ (1989). Primary structure of a protein C activator from Agkistrodon contortrix contortrix venom. Biochemistry, 28: 674679.

8. Rocha e Silva M, Beraldo WT \& Rosenfeld G (1949). Bradykinin, a hypotensive and smooth muscle stimulating factor released from plasma globulin by snake venoms and trypsin. American J ournal of Physiology, 156: 261-271.

9. Markland FS, Kettner C, Schiffman S, Shaw E, Bajwa SS, Reddy KN, Kirakossian H, Patkos GB, Theodor I \& Pirkle H (1982).
Kallikrein-like activity of crotalase, a snake venom enzyme that clots fibrinogen. Proceedings of the National Academy of Sciences, USA, 79: 1688-1692.

10. Tambourgi DV, dos Santos MC, Furtado NFD, Freitas NCW, Dias da Silva W \& Kipnis TL (1994). Pro-inflammatory activities in Elapidae snake venoms. British J ournal of Pharmacology, 112: 723-727.

11. Cavinato RA, Remold $\mathrm{H} \&$ Kipnis TL (1998). Purification and characterization of thrombin like activity from the venom of Bothrops atrox of different geographic regions. Toxicon, 36: 257-268.

12. Itoh N, Tanaka N, Mihashi $\mathrm{S} \&$ Yamashima I (1987). Molecular cloning and sequence analysis of CDNA for batroxobin, a thrombin-like snake venom enzyme. J ournal of Biological Chemistry, 262: 3132-3135.

13. Aguiar AS, Alves CR, Melgarejo $A \&$ Giovanni-De-Simone S (1995). Purification and partial characterization of a thrombinlike gyroxin enzyme from bushmaster (Lachesis muta rhombeata) venom. Toxicon, 34: 555-565.

14. Altschul $S F$, Madden $T L$, Schäffer $A A$, Zhang J , Zhang Z, Miller W \& Lipman DJ (1997). Gapped BLAST and PSI-BLAST: a new generation of protein database search programs. Nucleic Acids Research, 25: 3389-3402.

15. Köhler J \& Milstein C (1975). Continuous culture of fused cells secreting antibody of predefined specificity. Nature, 256: 495-497.

16. Bozzo S \& Retamal C (1991). Gel-perfect: Geles unidimensionales, un nuevo método densitométrico para computadores personales. Archivos de Biologia y Medicina Experimentales, 24: 181-184.

17. Shieh TC, Kawahata SI, Kihara H, Ohno M \& IwanagaS (1988). Amino acid sequence of a coagulant enzyme, flavoxobin, from Trimeresurus flavoviridis venom. J ournal of Biological Chemistry, 103: 596-605.

18. Rosenfeld G (1971). Symptomatology, pathology and treatment of snake bites in
South America. In: Bucherl W, Buckley E $\&$ Deulofeu V (Editors), Venomous Animals and Their Venoms. Academic Press, New York.

19. Kamiguti AS \& Cardoso J LC (1989). Haemostatic changes caused by the venoms of South American snakes. Toxicon, 27: 955-963.

20. Hatton MWC (1973). Studies on the coagulant enzyme from Agkistrodon rhodostoma venom. Isolation and some properties of the enzyme. Biochemical J ournal, 131: 799-807.

21. Burkhart W, Smith GF, Su J L, Parikh I \& LeVine H (1992). Amino acid sequence determination of ankrod, the thrombinlike $\alpha$-fibrinogenase from the venom of Agkistrodon rhodostoma. FEBS Letters, 297: 297-301.

22. Shu YY, Moran J B \& Green CR (1983). A thrombin-like enzyme from rattlesnake venom. Biochimica et Biophysica Acta, 748: 236-244.

23. Silveira AMV, Magalhães $A$, Diniz $C R$ \& De Oliveira EB (1996). Purification and properties of the thrombin-like enzyme from the venom of Lachesis muta muta. International J ournal of Biochemistry, 21: 863-871.

24. Serrano $S M T$, Reinhardt $M$, Sampaio CAM \& Fink E (1995). Purification, characterization and amino acid sequence of a serine proteinase, PA-BJ, with plateletaggregating activity from the venom of Bothrops jararaca. Biochemistry, 34: 7186-7193.

25. Zaganelli GL, Zaganelli MGM, Magalhães A, Diniz CR \& De Lima EM (1996). Purification and characterization of a fibrinogen-clotting enzyme from the venom of J aracucu (Bothrops jararacussu). Toxicon, 34: 807-819.

26. Wuster W, Thorpe RS \& Porto J (1996) Systematics of the Bothrops atrox complex (Reptilia:Serpentes:Viperidae) in Brazil: a multivariate analysis. Herpetologica, 52: 263-271. 